\title{
Effect of dietary levels of methionine + cystine on performance of broiler breeders
}

\author{
Paulo Cezar Gomes ${ }^{1}$, Cristina Amorim Ribeiro de Lima², Arele Arlindo Calderano ${ }^{2}$, Horacio \\ Santiago Rostagno ${ }^{1}$, Luiz Fernando Teixeira Albino ${ }^{1}$
}

1 Departamento de Zootecnia, UFV. Viçosa, MG.

2 Programa de Pós-graduação em Zootecnia - Departamento de Zootecnia, UFV. Viçosa, MG.

\begin{abstract}
The objective of this experiment was to evaluate levels of methionine + cystine levels for broiler breeders from 40 to 60 weeks of age. It was used 288 Cobb broiler breeders, distributed in a randomized experimental design with six levels of methionine+ cystine in the diets $(0.39 ; 0.47 ; 0.55 ; 0.63 ; 0.71$ and $0.79 \%)$, eight repetitions and six breeders per experimental unit. The diets were isocaloric and isoprotein (2,850 kcal ME/kg and $12.58 \% \mathrm{CP})$ and oferred at a fixed amount (155 g) per bird. For the entire studied period, by using polynomial analysis, it was observed a quadratic effect of methionine + cystine levels on the percentage of egg production, on number of eggs per hen housed, on number of eggs per hen and egg weight. There was also a linear effect on shell weight when it was calculated in relation to egg weight. The total methionine + cystine requirement for broiler breeders was calculated at $0.521 \%$ for percentage of egg production and number of eggs per hen, which corresponds to a daily intake of $808 \mathrm{mg}$ of methionine + cystine/day. The digestible methionine + cystine requirement for broiler breeders was estimated at $727 \mathrm{mg}$ for laying percentage and number of eggs per hen.
\end{abstract}

Key Words: eggs, requirement, sulfur amino acid

\section{Efeito dos níveis dietéticos de metionina + cistina no desempenho de matrizes pesadas}

\begin{abstract}
RESUMO - Com o objetivo de avaliar níveis de metionina + cistina para matrizes pesadas de 40 a 60 semanas de idade, conduziu-se um experimento com 288 matrizes da linhagem Cobb-500, distribuídas em delineamento inteiramente casualizado, com seis níveis de metionina + cistina nas dietas $(0,39 ; 0,47 ; 0,55 ; 0,63 ; 0,71$ e $0,79 \%)$, oito repetições e seis matrizes por unidade experimental. As rações foram isocalóricas e isoproteicas (2.850 kcal EM/kg e 12,58\% PB) e fornecidas em quantidade fixa (155 g) por ave. No período total estudado, por meio de análise polinomial, foi observado efeito quadrático dos níveis de metionina + cistina sobre o percentual de produção de ovos, o número de ovos por ave alojada, o número de ovos por ave e o peso dos ovos. Houve também efeito linear sobre o peso da casca quando calculado em relação ao peso dos ovos. A exigência de metionina + cistina total para matrizes pesadas foi estimada em 0,521\% para percentual de produção de ovos e número de ovos por ave, o que corresponde a uma ingestão diária de 808 mg de metionina + cistina total. A exigência de metionina + cistina digestível para matrizes pesadas é de 727 mg para percentual de postura e número de ovos por ave.
\end{abstract}

Palavras-chave: aminoácidos sulfurosos, exigência, ovos

\section{Introduction}

Broiler breeder rearing is characterized by utilization of specialized birds with high genetic potential. However, the lack of consistent data on the nutritional requirements of these birds makes it difficult to formulate correctly diets for the different periods of production in order to permit their genetic potential be expressed. Furthermore, knowledge of the nutritional requirements of the broiler breeders is important to optimize the use of food by birds and to formulate diets with minimal costs.

Methionine is considered the first limiting amino acid in diets for poultry. However, the recommendations of methionine + cystine found in the literature for broiler breeders in the production phase, besides to being scarce, show considerable variation. In the literature, it is observed recommendations of $785 \mathrm{mg}$ of methionine + cystine/bird/day (McDaniel et al., 1981), 870 mg (Pearson \& Herron, 1981) and $754 \mathrm{mg}$ (Wilson \& Harms, 1984), which differ from the 
$700 \mathrm{mg}$ for broiler breeders, as recommended by NRC (1994) for birds in peak production.

The objective of this experiment was to determine the nutritional requirements of metionine + cistine to broiler breeders at 40 to 60 weeks of age.

\section{Material and Methods}

The experiment was conducted at the Setor de Avicultura of the Departamento de Zootecnia at Universidade Federal de Viçosa (UFV). Cobb-500 line broilers were kept under traditional management conditions, described by Arenázio (1994) in the starting and growing phases (0-23 weeks) and in the first phase of production.

When completing 40 weeks of age, birds were weighed and distributed in the experimental units according to body weight, totaling $288 \mathrm{females}$. One male and six females were housed per experimental unit, a total of 48 experimental units. Each stall had $1.30 \mathrm{~m} \times 1.90 \mathrm{~m}$, totaling $2.27 \mathrm{~m}^{2}$ of area, four nests of $30 \times 30 \times 30 \mathrm{~cm}$ and feeder suitable for male and female. The difference between the feeders of males and females was based on the greater height of feeders for males and in the presence of exclusion grid installed in the feeders for females, preventing access of males to diet of females.

The experiment was conducted in completely randomized design with six treatments, eight replicates and six females per experimental unit. The treatments consisted of isocaloric and isonitrogenous diets $(2,850 \mathrm{kcal} / \mathrm{kg}$ and $12.58 \% \mathrm{CP}$ ) containing diferents methionine + cystine levels. The methionine + cystine levels were obtained from the basal diet supplemented (Table 1) with six levels of DL-methionine (98\%) in replacing corn starch. It was assumed that crystalline methionine is $100 \%$ available (Han \& Baker, 1994). The levels of DL-methionine used were $0.00,0.082,0.163,0.245,0.326$ and $0.408 \%$, resulting in a total of $0.390,0.470,0.550,0.630,0.710$ and $0.790 \%$ of methionine + cystine. The other nutrient levels used met at least the requirements specified for the period (NRC, 1994). It was provided daily, a fixed value of $155 \mathrm{~g}$ of feed per broiler breeder, totaling $930 \mathrm{~g}$ of feed per experimental unit.

The temperature in the shed was monitored daily at 12:00 p.m. by means of maximum and minimum thermometer, which was maintained in the center of the shed at the height of the birds. The average values recorded during the experimental period were 23.6 and $13.8^{\circ} \mathrm{C}$.

The experiment lasted 20 weeks and it was subdivided into five periods of 28 days. The birds were weighed at the beginning and end of the experiment for calculation of weight gain and average weight of birds. Egg production was recorded daily and eggs collected twice daily at
8:00 a.m. and 1:00 p.m. The average egg production per bird and average cumulative number of eggs per bird for period of 28 days were calculated according to the number of birds in the experimental units. To calculate the number of eggs per bird housed, it was used the number of birds housed at the beginning of the experimental period.

The eggs collected during the last six days of each period were used to determine average egg weight, yolk weight, shell weight, albumen weight, yolk weight/egg weight, shell weight/egg weight and albumen weight/egg weight.

To separate the components of eggs, it was used the cooking process, following the procedure adopted by Carnino (1992). The eggs were dipped in cold water, heated and removed 10 minutes after boiling. After cooling, the shell was broken and the parts were separated for weighing of the shell and yolk. The albumen weight was obtained as the difference of the total weight of the egg before cooking. The shells were air dried before weighing.

The statistical analysis was performed by using the program SAEG (System for Genetic Analysis and Statistics - UFV, 1996). The estimates of nutritional requirements were established by regression analysis and quadratic models, and/or discontinuous Linear Response Plateau (LRP), described by Braga (1983) according the best fit obtained for each variable.

Table 1 - Percentage composition of basal diet

\begin{tabular}{|c|c|}
\hline Composition & $\%$ \\
\hline Corn $(7.67 \% \mathrm{CP})^{1}$ & 11.671 \\
\hline Sorghum - LT $(9.65 \% \mathrm{CP})^{1}$ & 63.718 \\
\hline Soybean meal $(43.75 \% \mathrm{CP})^{1}$ & 11.492 \\
\hline Soybean oil & 1.461 \\
\hline Starch & 0.500 \\
\hline Limestone & 7.833 \\
\hline Dicalcium phosphate & 1.988 \\
\hline Mineral supplement ${ }^{2}$ & 0.050 \\
\hline vitamin supplement + choline $^{3}$ & 0.220 \\
\hline Salt & 0.450 \\
\hline L-lysine $\mathrm{HCl}$ & 0.482 \\
\hline L-threonine & 0.094 \\
\hline L-tryptophan & 0.031 \\
\hline Antioxidant (butylated hydroxytoluene) & 0.010 \\
\hline \multicolumn{2}{|l|}{ Nutritional composition } \\
\hline Crude protein (\%) & 12.58 \\
\hline Metabolizable energy (kcal/kg) & 2,850 \\
\hline Methionine + cystine total (\%) & 0.390 \\
\hline Lysine total $(\%)$ & 0.850 \\
\hline Tryptophan total (\%) & 0.170 \\
\hline Calcium (\%) & 3.500 \\
\hline Available phosphorus (\%) & 0.450 \\
\hline
\end{tabular}

${ }^{1}$ Values determined in the Laboratório de Nutrição Animal at UFV, according to Silva (1990).

2 Product composition: selenium - 0.25 mg; manganese - 106 mg; iron - 100 mg; copper - $20 \mathrm{mg}$; cobalt - $2 \mathrm{mg}$; iodine - $2 \mathrm{mg}$ and excipient qsp - 1,000 g.

${ }^{3}$ Product composition: vit. A - 10,000 IU; vit. D3 - 2,000 IU; vit. E - 30 IU; vit. B1 - 2 mg; vit. B6 - 3 mg; pantothenic acid - 12 mg; Biotin - 0.1 g; vit. K3 - 3 mg; folic acid - $1 \mathrm{mg}$; nicotinic acid - $50 \mathrm{mg}$; vit. B12 - $0.015 \mathrm{mg}$; excipient q.s.p. $1,000 \mathrm{~g}$, choline chloride $(60 \%)-72 \mathrm{~g}$ of choline. 


\section{Results and Discussion}

All parameters for the assessment of egg production were affected by the concentration of methionine + cystine in the experimental diets (Table 2). Quadratic effect was observed for percentage of posture, number of eggs per bird housed and number of eggs per bird, considering the average values of all experimental period. Similarly, Sá et al. (2007) evaluated the effect of increasing levels of methionine + cystine in the diet on performance of laying hens from 34 to 50 weeks of age and also observed quadratic effect on egg production.

Body weight of birds increased linearly when the levels of methionine + cystine were added to the diets. Value similar to the average weight of $4.08 \mathrm{~kg}$ obtained at the end of this experiment was reported by Lopez \& Leeson (1995), who studied the effects of diets with different levels of protein supplemented with synthetic amino acids, so as to maintain constant levels of methionine + cystine and lysine in broiler breeders during the breeding season and observed with a diet of $14 \% \mathrm{CP}$, average body weight of $4.11 \mathrm{~kg}$ in birds at 60 weeks of age.

The levels of total methionine + cystine used in the diets had a quadratic effect on egg weight and the estimated value of the requirement was $0.590 \%$. Similarly, Jordão Filho et al. (2006) evaluated the inclusion of increasing levels of methionine + cystine in the diet of laying hens from 20 to 44 weeks of age and observed a quadratic effect on egg weight of birds.

The great average weight of eggs obtained in the experiment (68.62 g) was expected because the birds were assessed at 40 to 60 weeks of age and it is known that egg size of broiler breeders increases as age advances. The average weight of eggs from broiler breeders at 44 weeks of age was $64.5 \mathrm{~g}$ according to Brake (1985). Harms (1991) observed that the average egg weight of broiler breeders was $71.7 \mathrm{~g}$ and $73.25 \mathrm{~g}$, respectively, from 52 to 57 and 58 to 61 weeks of age.
There was no effect of levels of methionine + cystine on the percentage of yolk and albumen. However, it was obtained a linear increase $(\mathrm{P}<0.05)$ for the average percentage of shell ( $\left.\hat{Y}=9.6640+0.8063 X ; R^{2}=0.55\right)$. Similarly, Jordan Son et al. (2006) observed no significant effect of levels of methionine + cystine in the diet on the percentage of yolk and albumen of eggs from laying hens from 20 to 44 weeks of age.

The mean percentages found in this study were $10.14 \%$ of the shell, $31.62 \%$ of yolk and $58.24 \%$ of albumen to egg weight of $68.62 \mathrm{~g}$. Thus, the observed percentage of yolk and albumen was higher than the values cited by Spratt \& Leeson (1987), who observed a mean percentage composition of eggs of broiler breeders at 40 weeks of age from $29.50 \%$ for yolk, $59.70 \%$ for albumen and $10.80 \%$ for shell to eggs with $63 \mathrm{~g}$. The egg yolk weight, according to these authors, increased with age of the breeders. The yolk content, expressed as percentage of total egg weight also increased whereas the albumen content decreased.

However, it should be considered that in this study that eggs were cooked to determine weight and percentage of its components. Hussein et al. (1992) observed that when the eggs are cooked, there is an increase in weight of yolk and a decrease on weight of albumen. The authors verified that these variations resulted in increased yolk:albumen ratio from 0.43 to 0.49 , respectively, for values of fresh and cooked eggs. Cherian et al. (1990) attributed the decrease of albumen moisture to migration of water from the albumen to the yolk when eggs are cooked.

The average values for all the experimental phase were used to determine the nutritional requirements by the broiler breeders. It could be seen by the quadratic model that levels of methionine + cystine that would result in maximum yield would be $0.680 \%$, considering the parameters percentage of egg production and number of eggs per hen in the period, and $0.667 \%$ for number of eggs per hen housed. However, the lowest value obtained for the sum of squared of deviations when the data were submitted to the LRP model

Table 2 - Performance, egg weight and relative weight of egg component of broiler breeders fed diets with different levels of methionine + cystine

\begin{tabular}{|c|c|c|c|c|c|c|c|c|c|}
\hline \multirow[t]{2}{*}{ Parameter } & \multicolumn{6}{|c|}{ Level of methionine + cystine (\%) } & \multirow[t]{2}{*}{ Mean } & \multirow[t]{2}{*}{ Effect } & \multirow[t]{2}{*}{ CV (\%) } \\
\hline & 0.39 & 0.47 & 0.55 & 0.63 & 0.71 & 0.79 & & & \\
\hline Posture (\%) & 47.60 & 53.20 & 56.76 & 56.43 & 57.10 & 56.82 & 54.65 & $\mathrm{Q}^{* *}$ & 7.26 \\
\hline Number of eggs per hen housed & 13.33 & 14.90 & 15.89 & 15.80 & 15.70 & 15.75 & 15.23 & $\mathrm{Q} * *$ & 6.94 \\
\hline Number of eggs per hen & 13.33 & 14.90 & 15.89 & 15.80 & 15.99 & 15.91 & 15.30 & $\mathrm{Q}^{* *}$ & 7.26 \\
\hline Body weight at 60 weeks of age & 3.94 & 3.97 & 4.16 & 4.19 & 4.12 & 4.12 & 4.08 & $\mathrm{~L}^{*}$ & 4.80 \\
\hline Egg (g) & 67.84 & 68.94 & 68.88 & 68.86 & 70.03 & 67.17 & 68.62 & $\mathrm{Q}^{*}$ & 3.25 \\
\hline Shell (\%) & 10.03 & 9.88 & 10.23 & 10.18 & 10.33 & 10.23 & 10.14 & $\mathrm{~L}^{*}$ & 2.60 \\
\hline Yolk (\%) & 31.43 & 31.15 & 32.05 & 31.10 & 31.89 & 32.13 & 31.62 & NS & 4.51 \\
\hline Albumen (\%) & 58.55 & 58.97 & 57.76 & 58.77 & 57.77 & 57.64 & 58.24 & NS & 2.56 \\
\hline
\end{tabular}

$\mathrm{L}=$ linear effect.; $\mathrm{Q}=$ quadratic effect; $\mathrm{CV}=$ Coefficient of variation.

$* *(\mathrm{P}<0.01) ; *(\mathrm{P}<0.05)$, by $\mathrm{F}$ test. 
indicates that this methodology better explained the behavior of the data and the requirements were estimated at $0.521 \%$ for the percentage of egg production and number of eggs per hen in the period and at $0.515 \%$ for number of eggs per hen housed (Table 3). The plateau was observed in mean values of $56.78 \%$ of posture, 15.90 eggs per hen and 15.78 eggs per hen housed.

As consumption was fixed at $155 \mathrm{~g}$ of feed/hen/day, these values correspond to an intake of $808 \mathrm{mg}$ for percentage of egg production and number of eggs per hen in the period and $799 \mathrm{mg}$ of methionine + cystine, considering the average number of eggs produced per hen housed. Considering the approximate digestibility of $90 \%$ for methionine + cystine (Rostagno et al., 2005), the requirements of digestible methionine + cystine for broiler breeders was estimated at $727 \mathrm{mg}$ for percentage of egg production and number of eggs per hen in the period, and $719 \mathrm{mg}$ for the average number of eggs produced per hen housed. The average percentage of egg production observed in the experiment was $54.65 \%$. Thus, the requirements suggested have to be adjusted in herds with different average percentage of egg production. The values obtained were higher than those recommended as the daily requirement of broiler breeders by Rostagno et al. (2005), of $765 \mathrm{mg}$ of methionine + cystine and $688 \mathrm{mg}$ of digestible methionine + cystine for broiler breeders with a body weight of $3.3 \mathrm{~kg}$. These values are also higher than that recommended by NRC (1994), $700 \mathrm{mg}$ of methionine and cystine/hen/day. On the other hand, they are much lower than the recommendation by the manual of handling of broiler breeder (Cobb 500) in this laying period, which is $0.62 \%$ or $961 \mathrm{mg} / \mathrm{hen} /$ day, considering a daily consumption of $155 \mathrm{~g}$ of feed. Although the recommendations contained in the manuals indicate considerable safety margin, the large discrepancy of the recommendations suggests that the levels suggested by NRC (1994) may be underestimated.

Table 3 - Regression equations of the quadratic model and Linear Response Plateau (LRP), nutritional requirements estimated and R ${ }^{2}$ of the different parameters

\begin{tabular}{|c|c|c|c|}
\hline Parameter & Quadratic equation & Requirement & $\mathrm{R}^{2}$ \\
\hline$\%$ posture & $\hat{Y}=4.9431+155.205 X-114.140 X^{2}$ & 0.680 & 0.96 \\
\hline Egg weigth & $\hat{Y}=54.9807+48.8793 X-41.4421 X^{2}$ & 0.590 & 0.53 \\
\hline Parameter & Line equation - LRP & Requirement & $\mathrm{R}^{2}$ \\
\hline$\%$ posture & $\hat{Y}=20.3275+69.9402 X$ & 0.521 & 1.00 \\
\hline Egg/hen/housed & $\hat{Y}=5.6915+19.5836 X$ & 0.515 & 1.00 \\
\hline Egg/hen & $\hat{Y}=5.6915+19.5836 X$ & 0.521 & 1.00 \\
\hline
\end{tabular}

\section{Conclusions}

The requirement for total methionine + cystine for broiler breeders is $0.521 \%$, which corresponds to an intake of $808 \mathrm{mg} / \mathrm{hen} /$ day of total methionine + cystine, and the requirement of digestible methionine + cystine for broiler breeders is $727 \mathrm{mg} / \mathrm{bird} /$ day.

\section{References}

ARENÁZIO, J.C.O. Manejo inicial e de recria. In: Manejo de matrizes. Campinas: Fundação APINCO de Ciência e Tecnologia Avícolas, 1994. p.51-72.

BRAGA, J.M. Avaliação da fertilidade do solo (ensaios de campo). Viçosa, MG: UFV, 1983. 101p.

BRAKE, J. Relationship of egg weight, specific gravity, and shell weight to time of oviposition and feeding in broiler breeders. Poultry Science, v.64, n.11, p.2037-2040, 1985.

CARNINO, F. Efeito de diferentes níveis de proteína na ração sobre o desempenho de poedeiras leves em produção. 1992. 263p. Tese (Doutorado em Zootecnia) - Universidade Federal do Rio Grande do Sul, Porto Alegre.

CHERIAN, G.; LANGEVIN, C.; AJUYAH, A. et al. Research note: Effect of storage conditions and hard cooking on peelability and nutrient density of white and brown shelled eggs. Poultry Science, v.69, n.9, p.1614- 1616, 1990.

COBB - VANTRESS. Complemento a la guia de manejo para la reproductora СОВB 500. Arkansas: Cobb-Vantress, Incorporated, 1996. 12p.

HAN, Y.; BAKER, D.H. Digestible lysine requirement of male and female broiler chicks during the period three to six weeks posthatching. Poultry Science, v.73, n.11, p.1739-1745, 1994.

HARMS, R.H. Specific gravity of eggs and eggshell weight from commercial layers and broiler breeders in relation to time of oviposition. Poultry Science, v.70, n.5, p.1099-1104, 1991.

HUSSEIN, S.M.; HARMS. R.H.; JANKY, D.M. Comparison of techniques for egg component yields. Poultry Science, v.71, n.2, p.373-377, 1992.

JORDÃO FILHO, J.; SILVA, J.H.V.; SILVA, E.L. et al. Exigências nutricionais de metionina+cistina para poedeiras semipesadas do início de produção até o pico de postura. Revista Brasileira de Zootecnia, v.35, n.3, p.1063-1069, 2006.

LOPEZ, G.; LEESON, S. Response of broiler breeders to low-protein diets. 1. Adult breeders performance. Poultry Science, v.74, n.4, p.685-695, 1995.

McDANIEL, G.R.; BRAKE, J.; BUSHONG, R.D. Factors affecting broiler breeder performance. 1. Relationship of daily feed intake level to reproductive performance of pullets. Poultry Science, v.60, p.307-312, 1981. 
NATIONAL RESEARCH COUNCIL - NRC. Nutrient requiriments of poultry. 9.ed. Washington, D.C.: National Academy of Sciences, 1994. 155p.

PEARSON, R.A.; HERRON, K.M. Effects of energy and protein allowances during day on the reproductive performance of broiler breeder hens. British Poultry Science, v.22, n.3, p.227-239, 1981.

ROSTAGNO, H.S.; ALBINO, L.F.T.; DONZELE, J.L. et al. Tabelas brasileiras para aves e suínos: composição de alimentos e exigências nutricionais. Viçosa, MG: UFV. 2005. 186p.
SÁ, L.M.; GOMES, P.C.; ALBINO, L.F.T. et al. Exigência nutricional de metionina + cistina digestível para galinhas poedeiras no período de 34 a 50 semanas de idade. Revista Brasileira de Zootecnia, v.36, n.6, p.1837-1845, 2007.

SPRATT, R.S.; LEESON, S. Broiler breeder performance in response to diet protein and energy. Poultry Science, v.66, n.4, p.683-693, 1987.

UNIVERSIDADE FEDERAL DE VIÇOSA - UFV. Sistema de análise estatística e genética - SAEG. Viçosa, MG: UFV, 1996. 96p.

WILSON, H.R.; HARMS, R.H. Evaluation of nutrient specifications for broiler breeders. Poultry Science, v.63, n.7, p.1400-1406, 1984. 